\title{
Ghanaian Settlers in Orimedu: Oju Ota, Gender, and Christianity in a Coastal Fishing Community
}

\author{
Adebayo Adewusi \\ Osun State University, Nigeria \\ shegunadebayo@gmail.com
}

\begin{abstract}
Orimedu was a relatively small coastal community in Ibeju-Lekki area of Lagos State before the area was connected to other parts of state through access roads and electricity in the late 1980s. This article traces the relationship of Orimedu, a predominantly traditionalist and Muslim community, with migrant and Christian fishermen from Ghana and from Togo over the past century or so. It explains that the Ghanaians were welcome despite their Christian identity because they simply adapted to the local religious landscape when they arrived and joined into the worship of Oju Ota, a local deity of fishermen. However, over the past three decades, the Ghanaians have established a Christian community which has been largely accepted.

The establishment of Christianity was linked to struggles over the gendered economy of the town. When it was found that the Ghanaians spent most of their profit in Ghana rather than locally, the people of Orimedu insisted that according to the covenant of Oju Ota, the fishermen should no longer sell their fish as this was traditionally regarded as a female occupation. This helped the indigenous Orimedu community to share in the profit made by the Ghanaians. However, by the 1980s and 1990s, when it became obvious that this arrangement made the local women very wealthy, the Ghanaians sought to recapture some of the profit by inviting their own wives to Orimedu to act as fish sellers and traders. This led to a more permanent presence of the Ghanaians in Orime$\mathrm{du}$, and eventually to the establishment - and acceptance - of Christian churches in the locality.
\end{abstract}




\section{Background to Orimedu history}

Orimedu is one of the major coastal communities in the Ibeju-Lekki local government area of Lagos State. The Ibeju-Lekki area, on the Atlantic coast in the southern part of Lagos State, has recently become a center of activity. As Lagos has expanded along the Lekki peninsula, the area has seen a growing presence of heavy and light industries, housing estates, ultra-modern markets, well developed beaches and different forms of social amenities that have attracted, and still attract, significant population from Lagos and its environs in recent years.

This development is however recent, and the present wealth of the area contrasts sharply with the situation a few decades ago when the area was virtually isolated from the Lagos metropolis. Geographically located between the lagoon and the Atlantic Ocean, the two bodies of water and their creeks were the only means of transportation to neighboring communities such as Ibeju (also known as Ibeju-Agbe), Lakowe, Eputu, Bogije, Okunraye, among others, and the nearest major town in this area; Epe. As the area was inaccessible by road, few Lagosians - especially those who considered themselves to be 'modern' would brave the canoes and speedboats that might transport them to Lekki.

The opening up of this part of Lagos State to road transport began in the early 1980s, when the first road that linked Lekki with Victoria Island was constructed. By 1990, Lekki-Ibeju was created as an independent local government area, and the development of a local government headquarters, first at Akodo and later at Igando Oloja, meant that some communities attracted new residents. Some people were also attracted to the area from Lagos to the west and Epe or Ijebu-Ode to the north (across the lagoon). However, the enduring absence of motorways linking Orimedu to the Lekki-Epe expressway, built in the 1980s, meant that its inhabitants continued to rely on the lagoon and the Atlantic Ocean for travelling and trading across short and long distances.

Like many communities in this area, Orimedu is an Ijebu settlement, but it also has a substantial non-indigenous population. Asking about the origin of the settlement's history, I was told that the founder was a hunter from Ile-Ife, who settled in Ibeju before he moved away and later settled at the present Orimedu. According to tradition, the founder with his entourage settled at a place where black earth was discovered, and it was from this that the name Ori medu (ori imedu i.e. on the black [fertile] earth) was derived. ${ }^{1}$

1. A different etymological explanation is offered in, T.O. Avoseh, "A Short History of Epe," in Toyin Falola, ed., Yoruba Gurus: Indigenous Production of Knowledge in Africa (Trenton NJ: Africa World Press, 1999), 197. 
Origin from Ile-Ife, the mythical "first" town of the Yoruba, is a claimed by many Yoruba settlements. For many traditionally-minded Yoruba people it is a true test of royal pedigree, but it is important to note that the central role accorded Ile-Ife in Yoruba history and mythology is also a product of the twentieth century. ${ }^{2}$ Interestingly, Avoseh reports that Ibeju was founded by settlers from Benin, ${ }^{3}$ while Orimedu was settled from Ile-Ife. This suggests that Ibeju was a town with diverse origins, which is confirmed by some historians of Ibeju and points to its historical importance in the region. This assumption is further confirmed by everal other local histories of origin. Apart from Orimedu, the settlements of Bogije and Elemoro, for example, also have a link to Ibeju in their migration stories.

Despite the importance of Ibeju, it is highly likely that Epe is either an earlier, or a second, centre of dispersal for the area, as all the towns mentioned above, including Ibeju, celebrate festivals similar to those in Epe, and after they have been celebrated in (Ijebu) Epe. It is therefore likely that Epe was another centre from which people dispersed and settled first in Ibeju before some moved further. Another possibility is that close trading relations between these settlements and Epe (which surely also included migrations) bound the settlements into a shared ritual calendar.

\section{The Arrival of "Lagos Orimedu" or followers of Kosoko}

While it is difficult to date the early history of Orimedu, it is remembered that by 1851, a new set of people came to settle with the existing inhabitants of the settlement. In that year, the famous Lagos king, chief, and trader Kosoko stayed in Orimedu for a while after leaving Lagos and before settling in Epe for eleven years. ${ }^{4}$ Some of his followers stayed back in Orimedu and formed another community known today as "Eko Orimedu" (Lagos people in Orimedu).

This may have been the first time the community received outsiders since their settlement at this location. However, Kosoko's movements after his flight from Lagos may also have followed an existing network of close local relationships between the Epe and other coastal Ijebu towns such as Orimedu. If the latter was the case, then it is likely that Orimedu had received smaller groups

2. From the colonial period onwards the ability to establish a direct link with Ile-Ife became a determining factor for the permission to wear a beaded crown among the Yoruba communities. National Archives Ibadan: Ije Prof.2. C23/1/2. A meeting of the Central Native Council where the Ooni Olubuse I was invited on the agitation for crown by Elepe of Epe in Sagamu, February 28, 1903.

3. Avoseh, A Short History of Epe, 197.

4. Personal interview with Alhaji Ganiu Adebisi, 70, in Orimedu, Lagos State, on October 18, 2016. He belongs to the Eko (Lagos) Orimedu group. 
of settlers from the network of towns that shared the festivals and ritual calendar of Epe.

The notion that Epe, Ibeju, Orimedu and other towns constituted a friendly network of towns is indirectly confirmed by accounts that suggest that Kosoko settled at Badore (a settlement near Orimedu) or at Ibeju before going to Epe. ${ }^{5}$ As oral accounts of historical place names are usually highly specific, the apparent confusion about where he settled may have arisen from the fact that these towns were known as a group, and one place name could stand in for the others. Equally, the links between these settlements may have meant that Kosoko spent time in each of them.

The main impact Kosoko's followers had on the existing community of Orimedu was the increase in population. But they also introduced Islam into a community where traditional worship was the norm. ${ }^{6}$ Unlike in Epe, Islam did not have much effect on the Orimedu community as traditional worship still held sway until many years later, although, like in Epe, Islam later became the main religion with which the community identified. ${ }^{7}$ One reason for the different role of Islam in the community may be that the differences between older and Lagos settlers in Orimedu was not as politicized as it became in Epe. One possible reason for this is that both groups saw themselves as different from the Fante-speakers that would arrive later!

\section{Fante-speaking fishermen in Nigeria and Orimedu}

As noted by Randall, a long tradition of mobility along West Africa's coast means that one in every three West Africans does not reside in her or his place of birth. ${ }^{8}$ This is certainly true today, when nationals of Cameroon, Ghana, Togo and Benin Republic fish in the coastal and marine waters of Nigeria during certain periods of the year. The fact that some of these people have

5. Robert S. Smith, The Lagos Consulate, 1851-1861 (Berkeley and Los Angeles: University of California Press, 1979), 153n32.

6. In a personal interview with the chief imam of Orimedu, he said people came from Epe to preach Islam in the community, but an elderly man, Pa Raheem Sheleru, 88, on October 17, 2016 asserted that Islam had been in existence in Orimedu and that the preachers from Epe only came to strengthen the Muslim community in Orimedu. It is therefore highly probable that there were Muslims in Orimedu even before the arrival of preachers from Epe.

7. Personal interview with Alhaji Segun Yekini Sanni at Orimedu, 57, on October 17, 2016.

8. Randall, S. "Review of Literature on Fishing Migration in West Africa -from a Demographic Perspective" Sustainable Fisheries Livelihoods Programme, SFLP, Report, (2005):31 www.sflp.org. Accessed on October 25, 2016 at 11:09pm. 
settled permanently in Nigerian coastal communities, and have intermarried with the hosts, confirms that this is not a recent practice.

There are six different types of fisheries migration, namely internal migration, short-term migration, seasonal migration, long term migration, permanent migration, and contractual migration. ${ }^{9}$ These can be summarized into internal migration, which is within the boundaries of a country, and trans-boundary or international migration. Internal migration is a commonplace within Nigeria; for example, there have been seasonal migrations of fishermen from different parts of Nigeria to other places, especially when the migration of fish is involved..$^{10}$ The majority of these fishermen usually returns to their base upon the expiration of season but others return only as visitors.

According to Fregene, the first group of fishing migrants settled on Lagos's western coast toward the end of the eighteenth century. He notes that the major motivation for migration by these fishermen was the possibility of a better catch as the fish species in their home area were much smaller in size. ${ }^{11}$ Gold Coast/Ghanaian fishermen are also found in large numbers in coastal communities from Badagry in the west of Lagos to Epe in the east. Their presence at Orimedu community was thus only part of a larger pattern. As most of the Ghanaian fishing migrants were men, most of them took semi-permanent residence in their new locations because of the distance from their home country, but visited home once a year or at other intervals to support and maintain contact with their families.

Massey et al. suggest that new migrants usually move into a place because of the existence of a previous migration. In other words, previous migrants facilitate the movement of their relatives and friends and lower the costs and risks of movement. ${ }^{12}$ Furthermore, Fregene observes that the existence of good network between the old migrants and the new ones in Lagos State coastal communities, ${ }^{13}$ which supports the view that successful migrants will likely

9. J-C Njock and L. Westlund, "Migration, Resources Management and Global Change: Experience from Communities in West and Central Africa," Marine Policy, 34 (2010): 753 754.

10. B. T. Fregene, "Profile of Fishermen Migration in Nigeria and Implication for Sustainable Livelihood", Conference paper published by the Oxford International Migration Institute, https://www.imi.ox.ac.uk/publications/profile-of-fishermen-migration-nigeria, accessed: October 10, 2016.

11. Ibid.

12. D.S. Massey et al, "Theories of International Migration: A Review and Appraisal," Population and Development Review, 19.3 (1993):431.

13. B. T. Fregene, "Profile of Fishermen Migration in Nigeria and Implication for Sustainable Livelihood", Conference paper published by the Oxford International Migration Institute, https://www.imi.ox.ac.uk/publications/profile-of-fishermen-migration-nigeria, accessed: October 10, 2016. 
attract friends and relatives from home to their host communities. The policy of unrestricted movement, which has always been the hallmark for the majority of West African coastal communities, created a platform for the multiplication of migrants and open access into the marine resources of the host communities. ${ }^{14}$

The high numbers of Ghanaian fishermen in Orimedu resulted from ongoing in-migration into Orimedu for over a century, which was facilitated by the earlier settlers in the community. Tradition has it that a member of the Eko [Lagos] Orimedu named Gborigi, who had contact with some Gold Coast fishermen in the course of his own fishing expeditions beyond Orimedu, introduced a few of them to Orimedu in the early 1900s. Since that period, the presence of the (now) Ghanaians has multiplied to the extent that they outnumbered the indigenous members of the community for several decades of the postcolonial period..$^{15}$ (Only recently, increased traffic from Lagos has meant that more Yoruba-speakers have bought land in the area). Although there are a number of other nationals resident in Orimedu, namely Togolese and Beninoise, the Ghanaians are the largest non-indigenous population in the community to date.

Upon their arrival in Orimedu the Ghanaians were better equipped in terms of skill and modern fishing techniques than their counterparts in the community. Unlike their hosts who were used to canoes and sails for fishing with smaller nets or baskets to provide for their basic needs, the migrants, who had been exposed to more efficient techniques of fishing, could embark on fishing in a more productive manner. The Ghanaians had a long history of exposure to better fishing techniques and rather improved fishing mechanisms like the seine 'drag net' along the beach since the 1890s, which could catch larger numbers of fish with less effort. ${ }^{16}$

Even at present, the Ghanaian superiority with regard to fishing is noticeable. While the majority of the indigenes still use small canoes, the Ghanaians fishermen have boats fitted with outboard engines, synthetic nettings such as beach seiners, set nets, gill nets and long lines that give them an edge over their

14. J.C. Njock, "Aménagement Participatif des Pêches en Zone Côtière au Congo, au Gabon, en Guinée et en Mauritanie," Pilot Project Terminal Report Sustainable Fisheries Livelihoods Programme, SFLP, Report, (2005):34, www.sflp.org, Accessed: October 25, 2016.

15. Personal interview with Alhaji Segun Yekini Sanni at Orimedu, Lagos State on October 17, 2016.

16. O. H. Por, Modernizing Ghanaian Fisheries: The Need for 'Social Carriers' of Technology (Oslo: Ad Notam, 1991), 199. 
landlords. ${ }^{17}$ The basic difference between the hosts and the migrants is that the former continued to see fishing as a means of satisfying their daily needs, while the latter approaches it as a business. The implication of this is that the ability of the Ghanaians to extend their fishing range and coverage beyond that of the indigenes, who used paddled canoes in shallow water, enabled them to establish a thriving community.

Finally, the hospitability of Orimedu to Ghanaians in the 1980s attracted many other settlers of Ghanaian origin in the coastal areas to the town when foreigners, mainly of Ghanaian origin, were expelled from Nigeria as part of the policy popularly referred to as "Ghana Must Go." However, the Ghanaians and Togolese who thronged to Orimedu at that time all escaped arrest by the law enforcement agencies, because the townspeople did not support the policy and police did not, at the time, venture into settlements like Orimedu. ${ }^{18}$

\section{The presence of Christianity in Orimedu}

The long-term presence of the Ghanaians in Orimedu has transformed the face of the settlement in various ways. During the colonial period, it may have brought other advantages to the town. Today the existence of colonial relics of a dispensary and a primary school are eloquent testimony to the fact that Orimedu was considered an important settlement in its own right, which was not overlooked by the colonial state. Given the pragmatic approach of the colonial state to settlement state, it is likely that these amenities were brought to Orimedu also because it was a sizeable settlement.

The Ghanaian presence has also introduced a sizeable Christian community into the town. It is said that the first set of Ghanaian settlers in this community were Christians, and this is indirectly confirmed by the fact that the Fante were part of the first group of people to have contact with the Christian missionaries in Ghana. Today all but one of the Ghanaian families in Orimedu are Christian. ${ }^{19}$ The prevalence of Christianity among the Ghanaians is manifested in the presence of various Christian denominations in the community. There are also few churches that are exclusively Ghanaian; the Musama Disco Christo Church (MDCC) and the Twelve Apostle Church do not admit non-Ghanaians into their midst. ${ }^{20}$

17. I observed the use and repair of this fishing equipment during my visits to the beach in Orimedu at different occasions.

18. Personal interview with Mr. Abraham Kwesi, 62, a Ghanaian fisherman in Orimedu on October 18, 2016.

19. There is only one Muslim Ghanaian family of Asante origin in Orimedu.

20. It is not clear if the church doctrine does not allow outsiders or if people are unwilling to join them. 
But despite the thriving Christian presence today, the public practice of Christianity in Orimedu is less than thirty years old. In nearby Akodo I was told by Reverend Salami Timothy that Islam and traditional religion were the two publicly practiced religions in the community until around $1990 .{ }^{21}$ In order to understand how and why Christianity remained such an excluded practice, we must look at the practices and beliefs of the past.

If we assume that Islam consolidated in Orimedu around 1851, Islam and traditional religion have coexisted for over a century and a half. Moreover, as indicated above, the introduction of Islam did not diminish the practice of traditional religion among the indigenes. Even today, traditional religion is much alive and their annual festivals bring all the indigenes together irrespective of the religion they profess. ${ }^{22}$ The festivals, collectively known as Eebi, usually feature the propitiation of many deities including Oro and Jigbo, and some other masquerades such as Katanpo, Alegbagba, Ogodo, Agila, Ajo, and Kilajolu. The beginning and the conclusion of the festival always end with sacrifice to the water goddess, Olokun. Meanwhile, two of the other numerous deities, Ogolumoyo and Oju Ota (or simply Ota), are also directly linked to water. The former is related to smaller bodies of water and is propitiated at ponds while the latter is directly related to the sea.

The accepted belief is that Oju Ota has a close connection with Olokun, the main goddess of the sea, and that the two (Olokun and Ota) must be propitiated together. Because Olokun is in the sea she determines whether the fishermen would catch fish or not. On the other hand, Oju Ota protects the fishermen and is the agent through which fishermen appeal to Olokun. To the people, Olokun and Ota jointly assist the fishermen in their occupation. For this reason, Oju Ota is usually propitiated once the fishermen observe a reduction in their catch. ${ }^{23}$ As a major beneficiary of these rituals, the Ghanaians also contribute to the celebration of these festivals, although their contribution is usually limited to monetary donation in support of the performance of these rituals.

What can be gleaned from the above is that the relatively slow development of Christianity in Orimedu can be located within the context of the prevalent belief in the traditional religion, especially the occupational deities Olokun and Ota. These patron deities of all fishermen have dominated the community life

21. Personal interview with Reverend Salami Timothy, 69, at Jesus People Assembly, Akodo via Orimedu, Lagos State on May 2, 2016

22. Personal interview with Alhaji Segun Yekini Sanni at Orimedu on 17 October, 2016. He said the Ghanaians also contribute to the celebration of these festivals, usually with monetary donations to perform some rituals because they are the major beneficiaries of the rituals.

23. Personal interview with Alhaji Segun Yekini Sanni at Orimedu on 17 October 2016. 
until very recently. It is interesting that the importance of these deities was not seen to be challenged by the practice of Islam. In the local understanding, there seems to be the idea that the healing and protective powers of Olokun and Islam can support each other rather than detract from one another. This may, however, reflect the fact that Muslims and non-Muslims have long lived together at Orimedu as indigenes, and that the success of their shared responsibility for the community convinced them that Olokun and Islam could coexist.

It is, however, remarkable that the local practice especially of Olokun was closely associated with a rejection of Christianity. This is likely the reason why the Roman Catholic Mission, which came to the community in the 1950s, only established a primary school, but not a church. ${ }^{24}$ While some of the rejection centers on the fact that Christianity is mostly practiced by strangers or outsiders whose lives do not depend on Olokun in the same ways as those of the locals, it is also directed against Christianity as a practice that does - or did - not belong to Orimedu.

Thus, when an indigene of the nearby community of Akodo established the first local church in 1990, the strangeness of having a church in the community occasioned a hostile attitude towards the church. When the indigenes formed the opinion that the Christians were antagonistic towards the traditional practices that protected the lives of community members, the church was burnt down. ${ }^{25}$ While the violence of this reaction - itself understood as a threat to the community - eventually contributed to the present situation, where churches can be freely established, many indigenes have a negative impression of Christianity as potentially challenging or undermining the community deities of Olokun and Ota. Even though some indigenes practice Christianity, it is perceived as a religion of foreigners whose primary loyalty may not lie with the community but rather with themselves. ${ }^{26}$ The perceived association of Christianity with outside interests suggests that the development of Christianity in Orimedu was delayed primarily because of the local hostility towards it.

However, there is no evidence suggesting that the Ghanaian fishermen practiced Christianity upon their settlement in Orimedu. This may have been

24. Unfortunately it has not been possible to find the relevant files of the Catholic mission. However the development is suggestive in the sense that evangelism, which ought to be the primary focus of the Christian body, was relegated to the background and a primary school was established instead.

25. Personal interview with Reverend Salami Timothy, Akodo via Orimedu, on May 2, 2016 at Akodo, Lagos State.

26. Personal interview with Alhaji Haliru Atiku Arikewuyo, Chief Imam of Orimedu, Lagos State, on May 2, 2016. He said Islam is the religion of his people and only few people were misled to embrace Christianity. 
for political reasons. As all Ghanaians found accommodation within the community and were allowed to engage in highly profitable activities without discrimination, they may not have felt the need to create a community of settlers that was clearly demarcated by religious difference. Also, they may have desisted from challenging the primacy of Olokun and Oju Ota in order not to worry their hosts, and thereby to encourage them to re-think their relationship with the migrants. While the fishermen were Christians, they had not come to the community to evangelize but to make a living through fishing.

It is also important to consider the possibility that many Ghanaians did not practice Christianity because they trusted in the efficacy of Olokun and Oju Ota and other traditional deities in their host community. Some of my respondents from the Ghanaian community of Orimedu explained that many Ghanaian fishermen embraced the traditional religion of the town. ${ }^{27}$ In our case, this may reflect the particular role of Oju Ota as a patron deity of fishermen: when we consider that the traditional deities of Orimedu had a proven track record of protecting the fishing community, it may also be that the immigrants accepted its efficacy during their stays at Orimedu, and that some of them returned to Christianity if and when they returned to their home communities. Either way, this process is a strong counter-example to the assertion that migration to the land of "unbelievers" usually strengthens the religious commitment of "believing" migrants. ${ }^{28}$

Today the popular belief among some Ghanaian Christians in Orimedu is that their ancestors were manipulated into joining the traditional religious cult in order to boost their catch. This may be another perspective on the dominance of Olokun and Oju Ota in Orimedu. As it is believed in Orimedu that all the fishermen, whether indigenes or migrants, must subscribe to the cult of Oju Ota in order to ensure fishing success, the cult was employed both to include the migrants into the community and to ensure that they did not challenge the status quo. Because the cult of Oju Ota is firmly maintained by the Orimedu "landlords," the migrants became recruits and tenants by joining the cult as junior members. As it will be shown shortly, the recruitment of the Ghanaians into the cult of fishermen became an effective tool to control their activities.

However, another reason is probably the fact that in the early decades of the Ghanaian presence, Ghanaian fishermen came to Orimedu without their wives - not to speak of children. As a result, they were not usually able to set

27. A personal interview with Pastor James Adewunmi, 53, a Ghanaian-born Yoruba who came from Ghana to settle in Orimedu at Orimedu, Lagos State on May, 2, 2016.

28. Peter van der Veer, Religious Nationalism: Hindus and Muslims in India (Beckley, CA: University of California Press, 1994), 119. 
up their own houses or compounds but depended on those in the host community in many ways, and in particular for female labor and company. This only changed in the 1980s and 1990s, when the decision of many Ghanaians to bring their wives to Orimedu meant that many of them built more permanent family houses, where they lived with their children. This in turn enabled the Ghanaian community to define its own boundaries more clearly. In other words, the prominence of Oju Oja and Olokun among the Ghanaians was reduced when they brought along their own women, who insisted on the group's Christian identity far more strongly than the men.

As I show in the last section of the article, the arrival of the Ghanaian women in turn was a result of the economic tensions arising from the greater productivity of the Ghanaian fishermen, which the Orimedu indigenes attempted to control through the gendered logic associated with the Oju Ota cult.

\section{Economic Competition, Oju Ota, and the Gendered Economy of Orimedu}

With better equipment, a larger population and strong determination, the Ghanaians in Orimedu built up an extensive fishing industry, and thus took over the economic leadership in fishing from their hosts. This set the stage for rivalry between the indigenes and the migrants, who have not shaken this role despite their long presence in the community, and who continue to be regarded as "tenants." Transforming Orimedu from a sleepy coastal community to a growing fish market that attracted people from outside, the Ghanaians were actually instrumental for the continued existence of Orimedu as a successful community, especially when many of the indigenes who had obtained Western education moved to larger settlements where they might enjoy jobs that were less demanding and dangerous than fishing. ${ }^{29}$ Despite the absence of motorways around the area, the water served as the means of transportation for fish buyers from Lagos, Epe, Agbowa, and other destinations, who appreciated the low prices, variety, and quality of fish and other sea foods offered by the Ghanaians in Orimedu.

However, a major complaint held by the Orimedu indigenes against their "tenants" was that the latter made money and did not spend it in - and for the community. As they saw it, the fishermen's practice of travelling to their home communities once a year to spend their money there was selfish, because it depended on the community's support and protection but did not re-

29. Personal interview with Alhaja Rabiatu Adunni, 70+, at Orimedu on October 6, 2016. 
turn the resulting wealth to it. ${ }^{30}$ These views hardened when the Ghanaians, mainly Fante speakers, were joined by some Togolese fishermen, and through these links the community also attracted some Beninoise laborers. Fishing has however remained the economic backbone of the people owing to their long time physical isolation from the major part of the state. Different views of what, or whether, the Ghanaians, as "tenants," owed to their host community led to a series of skirmishes over fishing and related issues. ${ }^{31}$

For example, apart from giving a certain percentage of their catch to the Oba and his chiefs as the traditional royalty, it was reported that some youths in the community were in the habit of demanding fish from the Ghanaians and this always caused frictions between them. Another source of conflict was that the Ghanaians sometimes damaged the nets set by the indigenes during their fishing expeditions. It is noteworthy that the Ghanaians have always acquiesced to the dictate of the community in the settlement of conflicts, except on an occasion in 1984 when a Ghanaian popularly known as Bole led some people out of Orimedu to settle in the neighboring Magbon Alade over his disaffection with the judgment over what he considered extortionist policy of the community.

In line both with the dictates of hospitality and the popular Yoruba proverb that states that a tenant must not compete with the landlord, the community decided after this event that it would not stop the business of the Ghanaians and other migrants but that it needed to ensure that it benefited from their success. After some discussion and negotiation, with representatives of the Ghanaian community, who wanted to remain at Orimedu, it was agreed that in order to raise funds for community development, the Ghanaians were to give a certain percentage of whatever they caught on their fishing expeditions to the host community as "rent."

Moreover, the community members insisted that in line with the gender roles associated with Oju Ota, the Ghanaian fishermen should desist from selling the fish caught while at Orimedu at the community market, or at any other market. To sell their wares, they had to do what Yoruba fishermen did and exchange the fish for goods or money at the sea shore rather than the market. As the Ghanaians were predominantly men, this meant that they would leave the trade of their fish largely to the women of Orimedu, who would then deal with potential buyers from outside through the market. ${ }^{32}$

30. Personal interview with Pastor James Adewunmi at Orimedu, Lagos State.

31. In my personal interview with Alhaji Segun Yekini Sanni at Orimedu he noted that the community later appealed to Bole and his group to return to Orimedu but that Bole refused their appeal.

32. Personal interview with Oba Hamzat Atiku, Onimedu of Orimedu, May 21, 2016 at Onimedu Palace, Orimedu, Lagos State. 
The latter agreement turned out to be an empowerment of the women of the community. Unlike in some parts of Nigeria where women engage directly in fishing, ${ }^{33}$ the tradition of Orimedu, and especially the cult of Oju Ota, does not allow for women fishing either in the lagoon or in the sea. While men go to the sea, mend the nets and repair the canoes, women sort, process and market the fish caught by men. They either smoke and dry the fish using the traditional method, or sell the fresh fish at a lower price. After the agreement between the Ghanaian fishermen and the indigenous inhabitants of Orimedu community, almost all fish caught by Ghanaians was bought by the women of the community, usually when the boats returned to the beach.

Like many (though not all) Yoruba communities, traditional Orimedu was a strongly male dominated community, and this translated into a low level of political or economic visibility for most women. When the rule that Ghanaian fish had to be sold to local women was first implemented, most women had so little capital that they had to purchase the fish on credit from the fishermen. Like the indigenous fishermen (and sometimes even the husbands of the female fish sellers!), the migrants had to sell to the women on credit, and the women would pay them back only after the sale of the fish, often without a specific date for payment. ${ }^{34}$ Due to the quality of the fish, and the high prices that could be obtained for Ghanaian-caught fish from outside buyers, this business was the path to greatness for many women in Orimedu who became the economic drivers of the community when they began to realize regular profits. ${ }^{35}$

The marketing and distribution of significant amounts of fish gave the women of Orimedu the chance to take on a position of affluence relative to their men. Even though they all started small, there emerged among the women wholesalers and retailers on the basis of temperament and acumen. Among the wholesalers, most women were attached to a particular boat which gave them easy access to fish which they partly processed themselves and also sold on to retailers. Eventually, some of these women even owned boats. ${ }^{36}$ Retailers mainly sold fresh fish in the local market, but others processed fish by smoking or drying and realized larger profits. Among these, some women were adventurous and travelled over long distances to bigger markets outside the commu-

33. Odulate, D.O et al, "Role of Women in Fisheries in Coastal Wetland Area of Ogun State, Southwest, Nigeria," Journal Agricultural Science and Environment, 12.1 (2012): 74.

34. Personal interview with Madam Jemilat Hamzat, 65, on October 6, 2016 at Orimedu, Lagos State.

35. Ibid.

36. Personal interview with Alhaji Segun Yekini Sanni on October 17, 2016. 
nity, including Epe, Ejinrin and Idumagbo on Lagos Island, often realizing a substantial profit for their wares.

It was through the role as middle (wo)men following the agreement with the Ghanaians that most of the women in Orimedu became wealthier than many of the men in the community. In addition to paying for boats of their own, they began to finance the fishermen or pay them in advance before they went on fishing expeditions. Some of the Ghanaians even became indebted to the traders and had to pay their debts with fish. This usually happened after a Ghanaians approached one of the wealthy women for a loan ahead of a trip to Ghana at the end of the year. Having spent the money in Ghana, they would then start the New Year by paying off their debts with fish. ${ }^{37}$

Moreover, as some of these women became the breadwinners in the family, they financed the education of their children outside of the community. Because of their greater appreciation of modern conveniences and their frequent travels to more urban communities, women also built most of the modern houses in the town. ${ }^{38}$ Some of the women who first rose to prominence in the fish business in Orimedu include Alhaja Mutiat Oyedele, Alhaja Wosilat Ajisebutu, Alhaja Iyabo Azeez, and Alhaja Shaba Folami. In their lifetime, these women were even noted as pillars of the fishing business because they provided funds for the men to embark on expeditions or to repair their boats. ${ }^{39}$

In more recent times, however, Ghanaians have responded to the loss of profit through the female control of fish marketing by bringing their wives to Orimedu to engage in the fish marketing business. The coming of social amenities such as road in 1989/1990 facilitated easy movement in and out of the community, and after it was built, many wives of the Ghanaian fishermen took advantage of the greater freedom of movement to break the indigenes' control of the fish trade.

This practice has not been challenged by the community, because even though the insistence that Ghanaians should not trade in fish indirectly arose from economic competition between indigenes or "landlords," and migrants or "tenants," it was founded on gendered difference rather than origin. Moreover, as Orimedu had already benefited greatly from the arrangement before the Ghanaian women arrived, it would appear selfish for the community now to exclude Ghanaian women from the opportunities of the trade.

37. Personal interview with Madam Jemilat Hamzat, 65, on October 6, 2016.

38. Personal interview with Alhaji Segun Yekini Sanni on October 17, 2016, while Pastor James Adewunmi also buttresses this point.

39. The era of women's dominance, however, elapsed upon the opening up of this area to outsiders. Men now make more profit from the fishing business than women. 
It may also be the case that the presence of the wives from Ghana means that the fishermen are seen to consider Orimedu a more permanent home, and many people expect that over time, the Ghanaians will be accepted as an integral part of Orimedu community. It may be in the light of the perception that the Ghanaians are now settled more permanently in Orimedu, and have begun to spend money there, that the religion with which they are associated has become acceptable, even if it is still viewed with suspicion. Thus it was the arrival of the Ghanaian women, itself a partial result of the gendered division of labor associated with Oju Ota, that established Christianity in Orimedu.

\section{Conclusion}

Over the course of the twentieth and twenty-first century, the relationship between the people of Orimedu and the Ghanaian fishermen illustrates the intersection of the relationship between indigenes and migrants, or "landlords" and "settlers," and between men and women. Initially, the Ghanaians were welcomed into a largely traditionalist community that had however already experienced transformation through the immigration from Lagos, and the arrival of Islam. As the Ghanaians adapted to the local religious landscape, they were welcome despite their Christian identity, but the non-permanent status of the Ghanaian migrants offended local perceptions of what the community should be like. Eventually, the people of Orimedu employed the medium of the religious cult or covenant of Oju Ota to force the Ghanaians to desist from selling fish. As local women took on a middleman position, the indigenous Orimedu community shared in the profit made by the Ghanaians. But as the local women became wealthy, the Ghanaians sought to recapture some of the profit by bringing their own wives to Orimedu to act as fish sellers and traders. This led to a more permanent presence of the Ghanaians in Orimedu, and eventually to the establishment - and acceptance - of Christian churches that demarcated the Ghanaian community more closely. 